\section{Infrastructure development and industrial sector productivity in Sub-Saharan Africa}

Infrastructure and industrial sector productivity Department of Banking and Finance, Nnamdi Azikiwe University, Awka, Nigeria

\begin{abstract}
Purpose - The purpose of this study is to examine whether the state of infrastructure development in SubSaharan Africa actually stimulates industrial sector productivity, using a panel data set of 17 countries spanning from 2003 to 2018.

Design/methodology/approach - The study used panel least square estimation technique to examine the relationship between the variables.

Findings - The result of the study indicates that the major factor that influences industrial sector productivity in Sub-Saharan Africa is their quantity and quality of telecommunication infrastructure. Analysis shows that the relatively low level of industrial sector productivity in Sub-Saharan Africa is largely due to their poor electricity and transport infrastructure and underutilization of water supply and sanitation infrastructure.

Practical implications - The government should partner with other developed countries of the world such as Germany, Japan, Sweden, Netherlands, Austria, Singapore, United States of America, United Kingdom, Switzerland and United Arab Emirates, which are the top ten countries in infrastructure ranking as currently released by the World Bank, to equally extend their quality infrastructure to their own country for enhanced industrialization.

Originality/value - The novelty of this research lies on the fact it is a cross-country study as against the few empirical studies that focused only on a single country. Also, the study made use of the four main indicators of infrastructure development in an economy, which are electricity infrastructure, transport infrastructure, telecommunication infrastructure and water supply and sanitation infrastructure, to examine its effect on industrial sector productivity in Sub-Saharan Africa.
\end{abstract}

Keywords Infrastructure development, Industrial sector productivity, Sub-Saharan Africa, Panel least square estimation

Paper type Research paper

\section{Introduction}

A well-industrialized economy is expected to have adequate infrastructure that will impact positively on the industrial sector of the economy which is seen as an engine of economic growth. Availability of adequate and efficient infrastructural set-up not only improves the quality of life of the people but also promotes rapid industrialization. The development of infrastructure in Africa is critical for fostering economic growth and improving the living standards of Africans. It contributes significantly to human development, poverty reduction and the attainment of the Sustainable Development Goals (African Development Bank, 2018b).

Development economists have considered physical infrastructure to be a precondition for industrialization and economic development, where physical infrastructure, in general,

JEL Classification - H54, D24, O55, C33

(C) Chukwuebuka Bernard Azolibe and Jisike Jude Okonkwo. Published in Journal of Economics and Development. Published by Emerald Publishing Limited. This article is published under the Creative Commons Attribution (CC BY 4.0) license. Anyone may reproduce, distribute, translate and create derivative works of this article (for both commercial and non-commercial purposes), subject to full attribution to the original publication and authors. The full terms of this license may be seen at http:// creativecommons.org/licences/by/4.0/legalcode

The authors are thankful to the anonymous reviewers of this journal for their extremely useful comments and suggestions to improve the quality of this paper. The usual disclaimer naturally applies.
Received 20 November 2019

Revised 14 January 2020 3 February 2020

Accepted 3 February 2020 
JED

22,1

92

consists of two parts as follows: economic infrastructure such as telecommunications, roads, irrigation and electricity and social infrastructure such as water supply, sewage systems, hospitals and school facilities (Murphy et al., 1989). The developed and developing world alike, count industrialization as a significant dynamics for growth and development, and the relationship between infrastructure and industrialization in any economy can be appreciated from the perspective of distribution of resources, which include production inputs and outputs, to and from industries. Thus, infrastructure and industrialization go hand in hand on the quest for sustainable development in any economy (Umofia et al., 2018).

Erenberg (1993) asserts that domestic and multinational companies will operate with less efficiency, and below their optimal level, should public infrastructures not be extended to them because they would have to incur an additional cost of building infrastructures of their own, and this will lead to duplication and wastage of the available scarce resources. In the production process, infrastructure facilities are considered to be intermediate inputs though they are output of their own industry. Their availability in adequate quantity and quality reduces input cost and raises the profitability thus permitting higher level of output for industries.

An adequate supply of infrastructure services has long been viewed as a key ingredient for economic development, but Sub-Saharan Africa ranks at the bottom of all developing regions in virtually all dimensions of infrastructure performance (World Bank, 2017a). World Bank (2017a) observes that there are varying trends in the region's infrastructure performance across key sectors. In telecommunications, Sub-Saharan Africa has seen dramatic improvement in the quantity and quality of infrastructure, and the gains are broad-based. Access to safe water has also risen, with 77 percent of the population having access to water in 2015, from 51 percent in 1990, but disparities between rural and urban access rates persist.

Also, the bank further observes that in the power sector, by contrast, the region's electricity-generating capacity has changed little in more than 20 years. At about 0.04 megawatts per 1,000 people, capacity is less than a third of that of South Asia and less than one-tenth of that of Latin America and the Caribbean. There is some variation by country, with little progress in electricity-generating capacity per capita in the region's low-income countries (LICs) and lower-middle-income countries (LMCs), but more than a doubling of capacity among upper-middle-income countries (UMCs). Access to electricity is low, at 35 percent of the population, with rural access rates at less than one-third of urban ones. Per capita consumption of energy in Sub-Saharan Africa (excluding South Africa) is $180 \mathrm{kWh}$, against 13,000 kWh per capita in the United States and 6,500 kWh in Europe.

The African Development Bank (2018a) estimates that electricity costs three times more in Africa than in comparable developing regions, and most manufacturers operating in West and East Africa have to rely on expensive backup generators as a primary energy source, which adversely affects their profit margins. At the same time, weak transportation networks hinder manufacturers' ability to capitalize on regional economies of scale. Transport infrastructure is likewise lagging, with the region registering the lowest road and railroad densities among developing regions. Sub-Saharan Africa is the only region where road density has declined over the past 20 years (1990-2011). Despite a doubling in access to improved sanitation facilities, the access rate remains low, at about 30 percent in 2015; the largest gain in access has been in rural areas and LICs.

Thus, this deficit in infrastructures poses a serious challenge to industrialization, as industries can only survive in an economy with good infrastructure. One of the key factors retarding industrialization in Sub-Saharan Africa has been the insufficient stock of productive infrastructure in power, water and transport services that would allow firms to thrive in industries with strong comparative advantages (African Development Bank, 2018a).

The main objective of this paper is thus to determine whether the state of infrastructure development in Sub-Saharan African region actually stimulates industrial sector productivity measured by labour productivity, which is the output per person employed 
during a given period of time. Most empirical literature on infrastructure development such as that of Calderón and Servén (2010), Fedderke and Garlick (2008), Ajakaiye and Ncube (2010), Hulten et al. (2006), Ayogu (2007), Ansar et al. (2016), Tatyana (2015), Kodongo and Ojah (2016) and Olufemi et al. (2013) have focused much on its effect on economic growth. The few empirical studies so far on its effect on industrial sector productivity, such as those of Umofia et al. (2018) and Gafer and Saad (2009), concentrated only on a single country. However, our empirical analysis will focus on the Sub-Saharan African region and will employ a comprehensive data set of 17 countries in the Sub-Saharan Africa. This data set is considered fairly large enough as it will increase the degrees of freedom and therefore enhance the credibility of our results. The study will make use of the four main indicators of infrastructure development in an economy, which are electricity infrastructure, transport infrastructure, telecommunication infrastructure and water supply and sanitation infrastructure, to examine its effect on industrial sector productivity in Sub-Saharan Africa.

\section{The state of infrastructure development in Sub-Saharan Africa}

The four main infrastructure development indicators in an economy are electricity infrastructure, transport infrastructure, telecommunication infrastructure and water supply and sanitation infrastructure. They are discussed below with specific emphasis on Sub-Saharan Africa.

\subsection{Electricity infrastructure}

According to the International Energy Agency (2017), 43 per cent of the population in SubSaharan Africa now has access to electricity. There has been some encouraging progress in recent years, with 26 million people gaining access annually since 2012, an almost tripling of the rate seen between 2000 and 2012. East Africa registered significant progress. As a result, electrification efforts outpaced population growth, for the first time in 2014, leading to a decline in the number of people without access since then. But progress overall has been uneven, and the number of people without access to electricity in Sub-Saharan Africa remains higher in 2016 than in 2000.

The number of people without access to electricity in Sub-Saharan Africa stopped increasing in 2013 and has since declined, led by strong efforts in Cote d'Ivoire, Ethiopia, Ghana, Kenya, Sudan and Tanzania. Since 2012, the pace of electrification has nearly tripled, relative to the rate between 2000 and 2012. While the number of people gaining access in SubSaharan Africa has increased in recent years in each of its subregions, progress has been uneven. In 2016, eight countries had an access rate above 80 per cent - Gabon, Mauritius, Reunion, Seychelles, Swaziland, South Africa, Cape Verde and Ghana - while most countries had a rate below 50 per cent and some had a rate below 25 per cent (See Figure 1 below).

Also, it was observed that Sub-Saharan Africa was vastly outperformed by the other benchmark developing regions in the power sector in 2012. The electricity-generating capacity of the region has changed little in over 20 years and is about 0.04 megawatts (MW) per 1,000 people - that is, less than a third of that of South Asia (with 0.15) and less than onetenth of that of Latin America and the Caribbean (World Bank, World Development Indicators cited in Calderón et al., 2018). This is shown in Table I below.

\subsection{Transport infrastructure}

Sub-Saharan Africa's road network comprises strategic trading corridors of not more than 10,000 kilometers that carry about $\$ 200$ billion of trade annually. The road access rate is only 34 percent, compared with 50 percent in other parts of the developing world, while transport costs are 100 percent higher (African Union, 2014). In 2011, Sub-Saharan Africa registered the
Infrastructure and industrial sector productivity 
JED
22,1

\section{4}

Figure 1.

Population without access to electricity in Africa by country, 2016

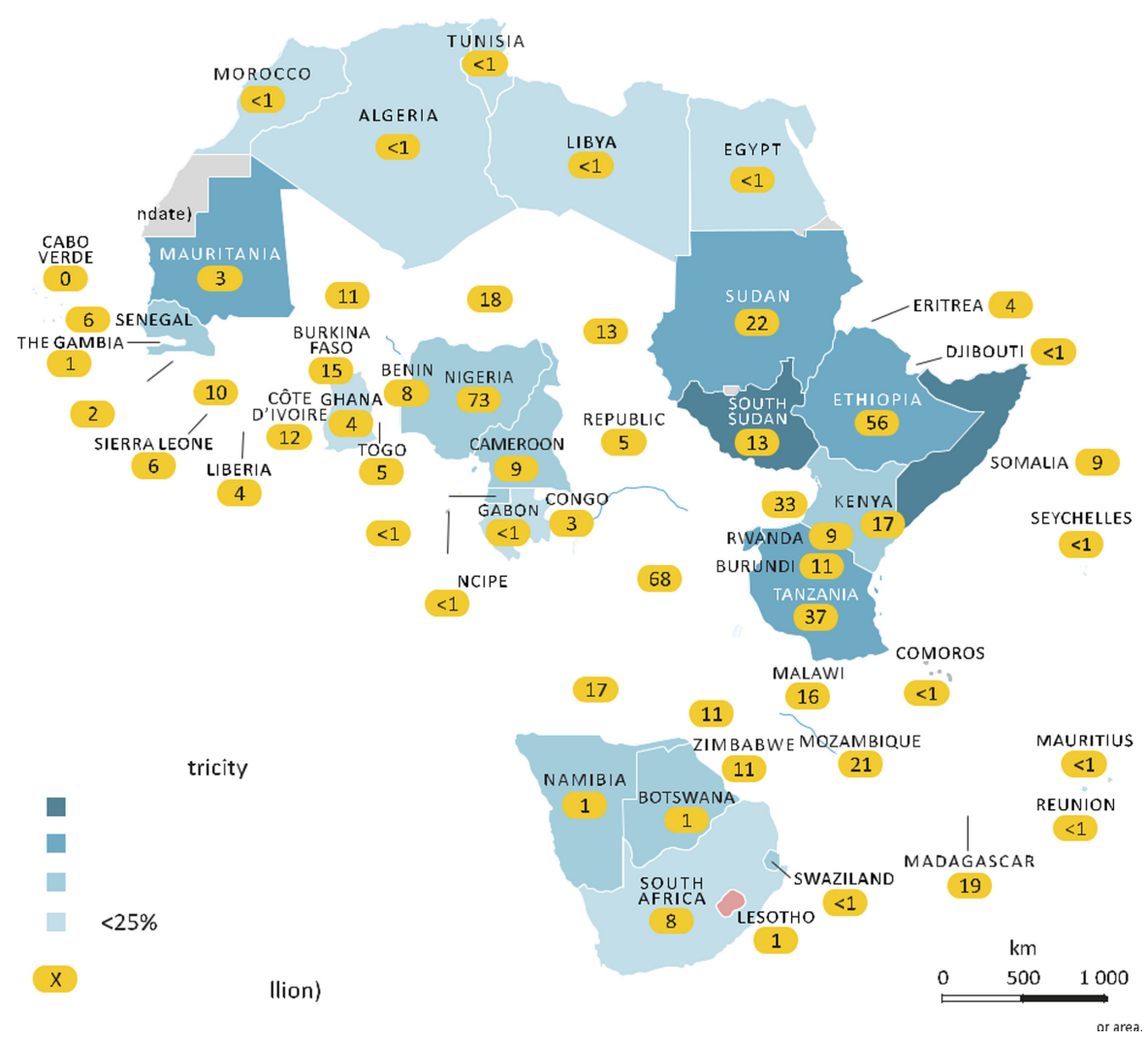

In Sub-Saharan Africa, 18 countries had electricity access rates above $50 \%$ in 2016

Source(s): World Energy Outlook, 2017

\begin{tabular}{|c|c|c|c|c|c|c|c|c|c|}
\hline & \multicolumn{6}{|c|}{ Region } & \multicolumn{3}{|c|}{ Income } \\
\hline & Year & SSA & SA & MENA & LAC & EAP & LIC & LMC & UMC \\
\hline \multicolumn{10}{|l|}{ Power } \\
\hline Electricity-generating $\mathrm{c}$ & 1990 & 0.03 & 0.07 & 0.25 & 0.3 & 0.15 & 0.02 & 0.06 & 0.33 \\
\hline Megawatts per 1,000 people (median) & 2012 & 0.04 & 0.15 & 0.4 & 0.43 & 0.84 & 0.03 & 0.06 & 0.72 \\
\hline \multicolumn{10}{|c|}{$\begin{array}{l}\text { Note(s): EAP = East Asia and Pacific; LAC = Latin America and the Caribbean; MENA = Middle East and } \\
\text { North Africa; SA = South Asia;SSA = Sub-Saharan Africa; LIC = low-income countries; LMC = lower-middle- } \\
\text { income countries; UMC = upper-middle-income countries } \\
\text { Source(s): International Energy Agency; World Energy Outlook }\end{array}$} \\
\hline
\end{tabular}

lowest road density among the developing regions under analysis. The analysis is shown in Table II below.

Moreover, Sub-Saharan Africa is the only region where road density has declined over the past 20 years. The density of the railroad network is likewise low, at less than $0.002 \mathrm{~km}$ per

Table I.

Electricity trends

Source(s): International Energy Agency; World Energy Outlook 


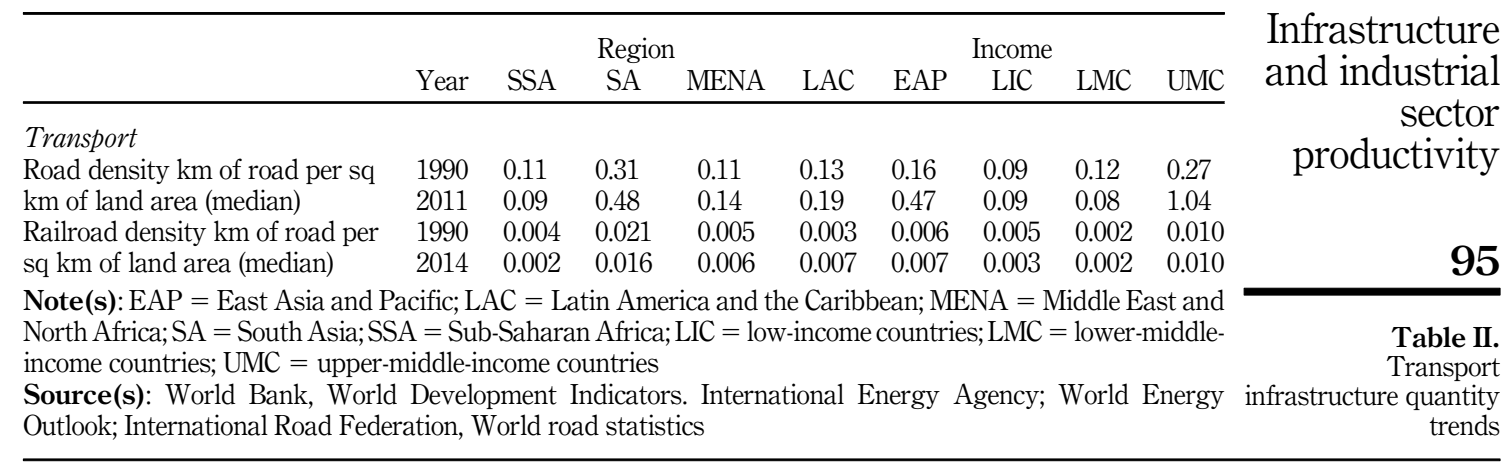

square $\mathrm{km}$ of surface area by 2014 , and this density has been declining. Nonetheless, the region's road density in relation to population is slightly higher than that of South Asia and only slightly lower than that of the Middle East and that of North Africa (Foster and BriceñoGarmendia, 2010).

In the area of port infrastructure, Sub-Saharan Africa has an extensive port system, which was built to serve the needs of individual countries and the neighboring hinterlands. Foster and Briceño-Garmendia (2010) report that several ports suffer from low capacity, particularly in terminal storage, maintenance and dredging capability and are poorly equipped and inefficient (with high port charges and low container handling rates). Finally, in the area of rail transport, about 47 railways operate in 32 countries in sub-Saharan Africa, with the total track rail length estimated at $82,000 \mathrm{~km}$ (Bullock, 2009).

\subsection{Telecommunication infrastructure}

Within Sub-Saharan Africa, progress is observed across all income groups, in terms of telecommunication infrastructure. Telecommunications density expanded at the fastest pace among the region's low income countries (LICs), although it started from low levels. Specifically, the number of fixed and mobile phones per 1,000 people among LICs grew from three in 1990 to 736 in 2014. The gap in telecommunication density relative to UMCs has narrowed significantly for LICs and LMCs over the past two decades. For instance, telecommunications density was twice as high in UMCs compared with LMCs in 2014 (while it was 11-fold in 1990). The fast growth of telecommunication density over the past two decades among the region's UMCs, increasing from 55 lines per 1,000 people in 1990, to 1,605 in 2014, has placed this group above the medians of other regions (World Bank, 2017). This is shown in Table III below.

\subsection{Water supply and sanitation infrastructure}

Water is an important resource for development. But, existing estimates show that about 300 million people in Sub-Saharan Africa experience water scarcity (UNECA, 2006). The region has ample water resources, but they are underdeveloped, unsustainably managed and underutilized, with only 5 percent of agriculture using irrigation (African Union, 2014). Indeed, recent UNICEF statistics show that, as of 2012 with the exception of Oceania where only 56 percent of the population has access to improved drinking water, in Sub-Saharan Africa with 64 percent, lags behind all regions and also falls below the least developed countries average of 66 percent. Overall, 748 million people worldwide did not have access 


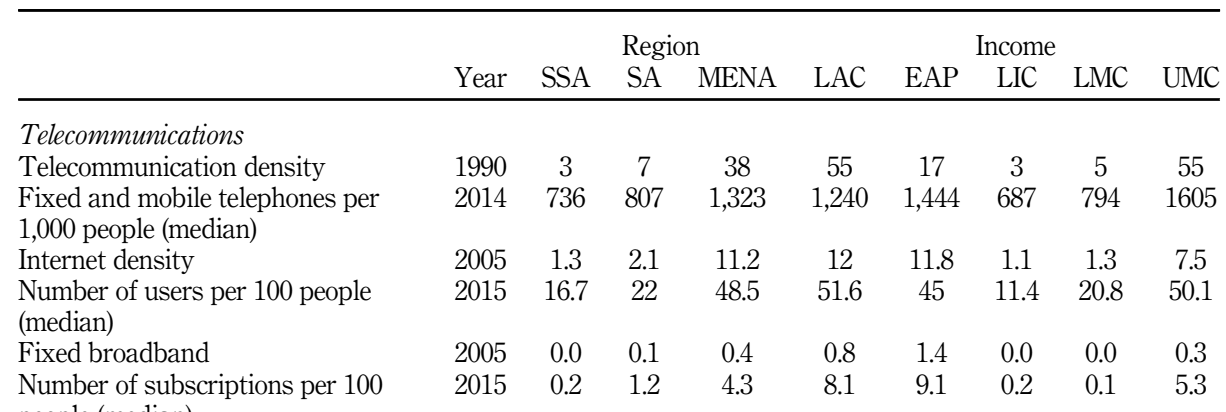

Table III.

Telecommunication infrastructure quantity trends
Note(s): EAP = East Asia and Pacific; LAC = Latin America and the Caribbean; MENA = Middle East and North Africa; SA = South Asia; SSA = Sub-Saharan Africa; LIC = low-income countries; LMC = lower-middleincome countries; UMC = upper-middle-income countries

Source(s): World Bank, World Development indicators

to improved drinking water in 2012; 43 percent (or 325 million) of those people live in Sub-Saharan Africa (WHO and UNICEF, 2014).

On the aspect of sanitation facilities, Sub-Saharan Africa has doubled total access rates to sanitation; however, they are still low relative to other benchmark regions. Sanitation access rates went from under 15 percent in 1990 to about 30 percent in 2015. In 2015, about 55 percent of the population of South Asia had access to sanitation facilities, while that proportion exceeded 80 percent for Latin America and the Caribbean and East Asia. With a median rate of 38 percent, access to sanitation has changed little for Sub-Saharan Africa's urban population. In the region's rural areas, only 25 out of 100 people had access to improved sanitation facilities in 2015, up from 9 in 1990 (World Bank, 2017) (see Table IV).

However, according to the African Development Bank (2018a, b) report on the composite Africa Infrastructure Development Index (AIDI), the top ten ranked countries in Africa in terms of level of infrastructure development in 2018 remained the same as in the AIDI

\begin{tabular}{|c|c|c|c|c|c|c|c|c|c|}
\hline & & & & gion & & & & Incom & \\
\hline & Year & SSA & SA & MENA & LAC & EAP & LIC & LMC & UMC \\
\hline Safe water sources & & & & & & & & & \\
\hline Total & 1990 & 51 & 69 & 92 & 86 & 84 & 48 & 59 & 91 \\
\hline Percent of population (median) & 2015 & 77 & 93 & 96 & 94 & 96 & 77 & 76 & 93 \\
\hline Rural & 1990 & 39 & 64 & 84 & 68 & 77 & 36 & 52 & 83 \\
\hline Percent of population (median) & 2015 & 67 & 92 & 92 & 87 & 93 & 67 & 57 & 81 \\
\hline Improved sanitation facilities & & & & & & & & & \\
\hline Total & 1990 & 15 & 20 & 77 & 66 & 72 & 11 & 27 & 71 \\
\hline Percent of population (median) & 2015 & 29 & 55 & 92 & 83 & 85 & 21 & 30 & 66 \\
\hline Urban & 1990 & 34 & 58 & 93 & 79 & 79 & 27 & 52 & 79 \\
\hline Percent of population (median) & 2015 & 38 & 73 & 96 & 87 & 88 & 38 & 37 & 70 \\
\hline Rural & 1990 & 9 & 5 & 65 & 38 & 64 & 7 & 18 & 64 \\
\hline Percent of population (median) & 2015 & 25 & 47 & 82 & 75 & 83 & 16 & 25 & 61 \\
\hline
\end{tabular}

Table IV.

Water supply and sanitation infrastructure access
Note(s): $\mathrm{EAP}=$ East Asia and Pacific; $\mathrm{LAC}=$ Latin America and the Caribbean; MENA = Middle East and North Africa; SA = South Asia; SSA = Sub-Saharan Africa; LIC = low-income countries; LMC = lower-middleincome countries; UMC = upper-middle-income countries

Source(s): World Bank, World Development Indicators 
rankings in 2016, namely, Seychelles, Egypt, Libya, South Africa, Mauritius, Tunisia, Morocco, Algeria, Cabo Verde and Botswana. Their specific ranking remains unchanged. These top ten countries are characterized principally by a robust investment performance in all sectors. Of these, five countries are in North Africa, and three are small island countries where tourism constitutes an important sector of their economies. They have therefore traditionally focused on improving infrastructure to attract visitors.

The bottom ten countries in the rankings are Central African Republic, Madagascar, Sierra Leone, Ethiopia, Eritrea, Democratic Republic of Congo, Chad, Niger, South Sudan and Somalia. Mozambique has moved from the bottom ten countries, replaced by the Central African Republic. Notably, this group is characterized by low performance in ICT, transport, power, water and sanitation. This is shown in Figure 2 below.

\section{Description of research variables}

The variables used in this study are made up of dependent, independent and control variables. They are discussed as follows:

\subsection{Dependent variable}

3.1.1 Industrial sector productivity. In this study, the labour productivity is used as a measure of industrial sector productivity. The industrial sector of an economy is seen as an engine of economic growth and as such, adequate infrastructure will help boost their productivity.

3.1.2 Explanatory variables. Four explanatory variables were used in this study, which is the measure of infrastructure development in an economy, and they are electricity infrastructure, transport infrastructure, telecommunication infrastructure and water supply and sanitation infrastructure. They are discussed as follows in relation to how they influence industrial sector productivity.

3.1.3 Electricity infrastructure. Electricity infrastructure has great effect on the growth of the industrial sector of an economy as it will enable industries to operate at a low cost. With constant power supply, firms will no longer have to seek for alternative source of power. Industries operate on a daily basis with heavy machines and equipment and thus need steady power supply to avoid disruption in the production process. This will ensure continuous flow in the production process and will in turn increase their productivity and profitability.

Electricity offers numerous advantages over other energy carriers, enabling far more efficient lighting (Fouquet, 2008), information and communication technologies and more productive organization of manufacturing (Kander et al., 2014). Production requires energy to carry out work to convert raw materials into desired products and to transport raw materials, goods and people. In an economic sense, energy performances add value to intermediate products as they are progressively transformed into final consumer goods; electric power is of fundamental importance to the economic, social and industrial development of a nation. Several empirical studies such as those of Abbas and Choudhury (2013), Chandran et al. (2010), Phiri and Bothwell (2015) and Lean and Smyth (2014) have all found a positive relationship between electricity infrastructure and economic growth. For the purpose of this study, the electricity index will be used as a proxy for electricity infrastructure. The electricity index consists of the electricity production of a given country, including the energy imported from abroad. This includes both private and public energy generated. This indicator is measured in millions of kilowatt-hour produced per hour and per inhabitants.

3.1.4 Transport infrastructure. Transport infrastructure such as roads, railways and ports helps to expand trade, to make business more productive and to reduce prices for consumers. Good transport infrastructure will enable industries to easily move raw materials and finished goods to and from the business. Thus, any significant disruption of the flow of goods and
Infrastructure and industrial sector productivity 
JED

22,1

98

Figure 2.

The composite Africa Infrastructure

Development Index (AIDI), 2018

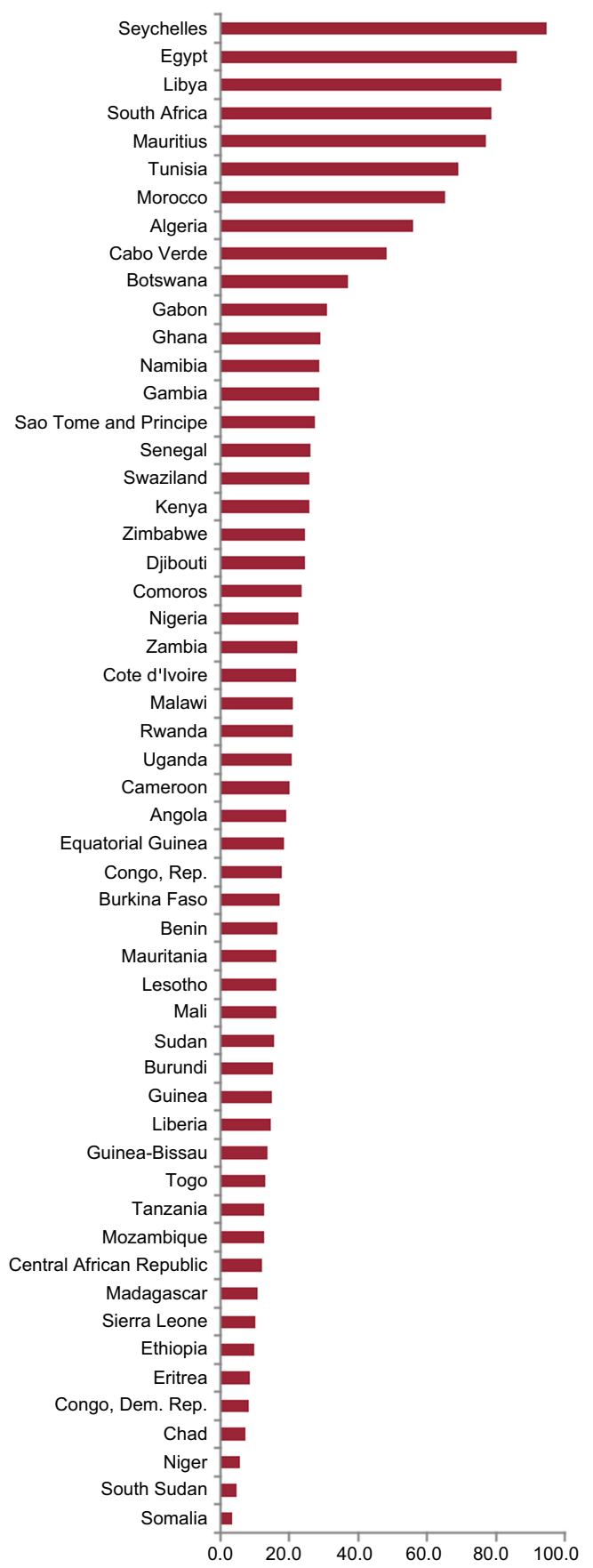

Source(s): Africa Development Bank (ADB), 2018 
people will impact economically a great number of businesses and individuals adversely, (Smith, 1994). Rodrigue and Nottemboom (2013) disclose that efficient transportation systems provide economic and social opportunities and benefits such as better accessibility to markets, employment, additional investments, reduced cost of business operation and time-saving product delivery. In a study conducted by Limao and Venables (2001), on the relationship between infrastructure, geographical disadvantage, transport costs and trade, they found out that a deterioration of infrastructure raises transport costs and reduces trade volume. Hence, low level of transport infrastructure will increase transport cost and will invariably reduce industrial sector productivity as industries rely heavily on good transport infrastructure for the conveyance of raw materials and finished goods.

Bad roads usually lead to crashing of trucks and vehicles that are carrying raw materials from their source of supply and finished goods to places of consumption, and this could result in potential loss on investment, and the profitability of the firm will be greatly affected. Past empirical studies on transport infrastructure such as those of Deng et al. (2014), Hong et al. (2011), Berechman et al. (2006), Cantos et al. (2005), Wing et al. (2008) and Gafer and Saad (2009) have all found a positive relationship between transport infrastructure and economic growth. The transport index is used as proxy for transport infrastructure which is measured by total paved roads ( $\mathrm{km}$ per 10,000 inhabitants) and total road network in $\mathrm{km}$ (per $\mathrm{km}^{2}$ of exploitable land area).

3.1.5 Telecommunication infrastructure. Telecommunication refers to the exchange of information by electronic and electrical means over a significant distance. Telecommunication infrastructure includes telephones, telegraph, radio, microwave communication arrangements, fibre optics, satellites and the Internet. Internet as a crucial tool of telecommunication infrastructure has significant relationship with the industrial sector of an economy, as all of the latter's transaction flow, accounts and documents largely rely on Internet directly. Telecommunication infrastructure facilitates electronic commerce, which refers to the buying and selling of goods or services using the internet and the transfer of money and data to execute these transactions. It is often used to describe the sale of physical products online. With telecommunication infrastructure, industries can conduct product research online to know about the new products and services that are evolving within the country and in other countries of the world. Also, products and services can be advertised online. Industries can utilize the Internet to get the information and location about that market which offers the highest price for their products. This helps to enhance sales and productivity. Previous empirical studies such as those of Datta and Agarwal (2004), Levendis and Lee (2013), Mehmood and Siddiqui (2013), Ahmed and Krishnasamy (2012), Shiu and Lam (2008a), Yoo and Kwak (2004), Cieslik and Kaniewsk (2004), Chakraborty and Nandi (2011), Dutta (2001), Roller and Waverman (2001), Hardy (1980), Greenstein and Spillar (1996) and Norton (1992) have attempted to examine the telecommunication impact over the economic development, and all of them confirmed that there is a strong positive relationship that exists between telecommunication infrastructure and economic development of a country.

However, Information and Communication Technology (ICT) Index is used as a proxy for telecommunication infrastructure. The ICT index measures the total phone subscriptions (per 100 inhabitants) and number of internet users (per 100 inhabitants).

3.1.6 Water supply and sanitation infrastructure. Water is connected to every form of life on earth and is a basic human need, equally important as air. Adequate and regular water supply is of great necessity for the survival of the industrial sector, which is the productive sector of an economy. The industrial sector relies heavily on the agricultural sector for the supply of raw materials. The agricultural sector needs constant water supply in the form of irrigation so as to ensure regular production and supply of raw materials to the industrial sector. In addition to this, industries need regular supply of safe and clean water to transform raw materials into finished goods. Thus, access to safe water is needed for the growth and
Infrastructure and industrial sector productivity 
JED

22,1

100

survival of the industrial sector and the economy at large. The water supply and sanitation index will be used as a proxy for water supply and sanitation infrastructure which measures improved water source (percentage of population with access) and improved sanitation facilities (percentage of population with access)

3.1.7 Control variables. The control variables were introduced in order to take cognizance of other factors that affect industrial sector productivity. This will act as a check regressor to determine the explanatory power of the model so as to enhance the robustness of our research findings. The control variables used in the study are capital, labour, lending rate, credit to private sector and military expenditure. They are discussed as follows in relation to how they influence industrial sector productivity.

3.1.8 Capital. Capital involves assets such as equipment, inventories, tools, transportation assets and electricity. The industrial sector of an economy needs capital goods to replace the older ones that are used to produce goods and services. Improved capital goods increases labour productivity, making industries more productive and efficient. Newer equipment or factories could lead to more products being produced at a faster rate and thus increases industrial sector productivity. The gross capital formation (annual percentage growth rate) will be used as a proxy for capital.

3.1.9 Labour. Labour represents the human factor in producing the goods and services of an economy. Industries rely heavily on the availability of vibrant and skilled labour that will help in the transformation of raw materials into finished goods. For the purpose of this study, labour force participation rate's total (per cent of total population ages $15+$ ) will be used as a proxy for labour.

3.1.10 Lending rate. The lending rate refers to the rate at which commercial banks grant loans to the industrial sector of the economy. Higher lending rate of banks discourages people from borrowing for investment purposes and will in turn reduce the productivity of the industrial sector and vice versa. Lending rate of commercial banks to the deficit sectors is usually influenced by the rate of the Central Bank.

3.1.11 Credit to private sector. Olowofeso et al. (2015) defined credit to private sectors as financial resources provided to the private sector, such as loans and advances, purchases of nonequity securities, trade credits and other accounts receivable, which establish a claim for repayment. Adequate credit to the industrial sectors of the economy will increase the level of investment and productivity and vice versa. For the purpose of this study, ratio of credit to private sector to gross domestic product will be used as a measure of credit to private sector.

3.1.12 Military expenditure. This refers to government expenditure on defense. Government military expenditure will create a conducive environment that is devoid of internal and external aggression, for people to do business. This will ensure that people's investments are safe and will increase the level of investment and productivity of industries. The ratio of government military expenditure to GDP will be used as a proxy for military expenditure.

\section{Model specification and data sources}

Consistent with the literature discussion, the industrial sector productivity model may be specified as follows.

$$
\mathrm{ISP} i t=\alpha 0+\alpha 1 \mathrm{INFD}+\beta \Sigma \mathrm{CV} i t
$$

where ISP is industrial sector productivity, INFD is infrastructure development and $\Sigma$ CVit is a vector of control variables which comprise capital, labour, lending rate, credit to private sectors and military expenditure for the representative countries. Industrial sector productivity is proxied by labour productivity which is the output per person employed 
during a given period of time; Infrastructure development is proxied by electricity index, transport index, ICT index and water supply and sanitation index. The final equation may be written as follows.

$$
\begin{aligned}
\mathrm{LP} i t= & \alpha 0+\alpha \mathrm{EINDEX} i t+\alpha 2 \mathrm{TINDEX} i t+\alpha 3 \mathrm{ICTINDEX} i t+\alpha 4 \mathrm{WSSINDEX} i t \\
& +\alpha 5 \mathrm{GCF} i t+\alpha 6 \mathrm{Lit}+\alpha 7 \mathrm{LR} i t+\alpha 8 \mathrm{CPS} i t+\alpha 9 \mathrm{MEXP} i t+\varepsilon i t
\end{aligned}
$$

For ease of interpretation of our result and to make all variables to be in the same state, we transform the variables to their natural logarithm, thus having elasticity coefficients as opposed to instantaneous rates of change. Transforming the above model into natural logarithm, we have the following:

$$
\begin{aligned}
\text { LLP } i t= & \alpha 0+\alpha \text { LEINDEXit }+\alpha 2 \text { LTINDEXit }+\alpha 3 \text { LICTINDEXit }+\alpha 4 \text { LWSSINDEXit } \\
& +\alpha \text { LGCFit }+\alpha 6 \text { LLit }+\alpha \text { 7LLR } i t+\alpha 8 \text { LCPSit }+\alpha 9 \text { LMEXPit }+\varepsilon i t
\end{aligned}
$$

Where LLPit $=\log$ of labour productivity (output per person employed) for country $i$ at time $t$; LEINDEXit $=\log$ of electricity index for country $i$ at time $t$; LTINDEXit $=\log$ of transport index for country $i$ at time $t$; LICTINDEXit $=\log$ of Information and Communication Technology Index for country $i$ at time $t$, LWSSINDEXit $=\log$ of Water Supply and Sanitation Index for country $i$ at time $t$, LGCF $i t=\log$ of gross capital formation (at annual percentage growth rate) (proxy for capital) for country $i$ at time $t$, LLit $=\log$ of labour (labour force participation rate, total (per cent of total population ages 15+), for country $i$ at time $t$, LLRit $=\log$ of lending rate for country $i$ at time $t$, LCPSit $=\log$ of ratio of credit to private sector to GDP for country $i$ at time $t$, LMEXPit $=\log$ of ratio of military Expenditure to GDP for country $i$ at time $t$, sit $=$ error term.

The models are estimated via panel data analysis on the unrestricted specification. Subscript " $"$ " stands for 16 years from 2003 to 2018 and " $i$ " stands for 17 countries.

For the purpose of this study, we used annual times series data spanning from 2003 to 2018 (16 observation) for 17 selected Sub-Saharan African countries i.e. Nigeria, South Africa, Kenya, Mauritius, Botswana, Mauritania, Burkina Faso, Democratic Republic of Congo, Gambia, Guinea Bissau, Liberia, Madagascar, Malawi, Mali, Togo, Tanzania and Uganda. The selection of countries and length of study period are determined by the availability of data for all required variables. All variables are obtained from the World Bank, World Development Indicator (WDI) and Africa Development Bank (ADB) report on Africa Infrastructure Development Index (AIDI) via World Bank's and Africa Development Bank's online database (2018). The data for labour productivity, capital, labour, lending rate, ratio of credit to private sector to GDP and ratio of military expenditure to GDP were extracted from World Bank database while data on electricity index, transport index, ICT index and water supply and sanitation index were extracted from Africa Development Bank database.

\section{Empirical results and discussion}

\subsection{Test of multicollinearity}

Gujarati et al. (2012) state that if the correlation coefficient between two variables is in excess of 0.8 , multicollinearity is a problem. Multicollinearity, a phenomenon in statistics, occurs when two or more independent variables within a stated model are confirmed to portray a great height of correlation with each other. When this happens, the estimated coefficient of the variables may be caused to vary intermittently when the model or data are modified. A variable that is meant to be significant becomes insignificant due to the problem of multicollinearity. An achievable technique to circumvent multicollinearity is to run a priori
Infrastructure and industrial sector productivity

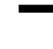


JED

22,1

102

correlation analysis of the variables that will be included in a model and removing any variable noticed to possess a great degree of correlation coefficient from the model.

However, this study found no evidence of high or exact multicollinearity, as all correlation coefficients of the independent variables of the model did not exceed the 0.8 bench mark. Put differently, the result indicates absence of multicollinearity. Therefore, we can include all variables in our empirical model. This result is shown in Table $\mathrm{V}$ below.

\subsection{Panel unit root test}

Panel unit root test is necessary to know the order of integration of the variables before we proceed to macro panel data analysis. We use unit root test proposed by Levin et al. (2002), also known as LLC. Breitung (2000), Im et al. (2003), also known as IPS, and Fisher (1932) type test using ADF and PP Test (Mandala and Wu (1999) and Choi (2001). The result is presented in Table VI below;

The panel unit root test statistics as shown in Table VI above suggest that only LLP, LGCF, LLR and LMEXP are stationary at level at five per cent significance level. LEINDEX, LTINDEX, LICTINDEX, LWSSINDEX, LL and LCPS are not stationary at level but became stationary at first difference at five per cent level of significance. Therefore, we can conclude that the panel variables in our study are integrated in level zero, $\mathrm{I}(0)$ and order one, I(1).

\subsection{Estimation of the panel data}

The panel data for the cross-country study was estimated using panel least square regression method. Before estimating the panel least square, we first of all estimate the Hausman test to determine whether to use fixed effect or random effect. The fixed effect is a statistical model in which the model parameters are fixed or have nonrandom quantities while the random effect model is the model in which all or some of the models are considered as random variables. The group means are a random sample from a population. The result of the Hausman test is estimated below in Table VII.

\subsection{Decision rule}

Null hypothesis: Random effect model is appropriate

Alternative hypothesis: Fixed effect model is appropriate

If the $p$-value is less than 0.05 , we reject null hypothesis and accept alternative hypothesis

From the above analysis, the $p$-value $(0.0855)$ is greater than 0.05 . Therefore, we accept the null hypothesis that random effect model is appropriate. This is estimated below.

The result reported in Table VIII indicate that a small share variation in industrial sector productivity can be explained by a number of factors, namely, electricity infrastructure, transport infrastructure, telecommunication infrastructure, water supply and sanitation infrastructure, capital, labour, lending rate, credit to private sectors and military expenditure. As a group, these factors account for about 25 per cent of the variability in industrial sector productivity. Indeed the adjusted R2 is very low for a cross-country regression.

The coefficient of the electricity index and transport index shows a negative insignificant and positive insignificant effect respectively on industrial sector productivity. This shows that electricity index and transport index do not influence industrial sector productivity in SubSaharan Africa. This was in tandem with the World Bank (2017a) recent observation that was earlier cited at the introductory section of the study that the region's electricity-generating capacity has changed little in more than 20 years. At about 0.04 megawatts per 1,000 people, capacity is less than a third of that of South Asia and less than one-tenth of that of Latin America and the Caribbean. Per capita consumption of energy in Sub-Saharan Africa (excluding South Africa) is $180 \mathrm{kWh}$, against $13,000 \mathrm{kWh}$ per capita in the United States and 


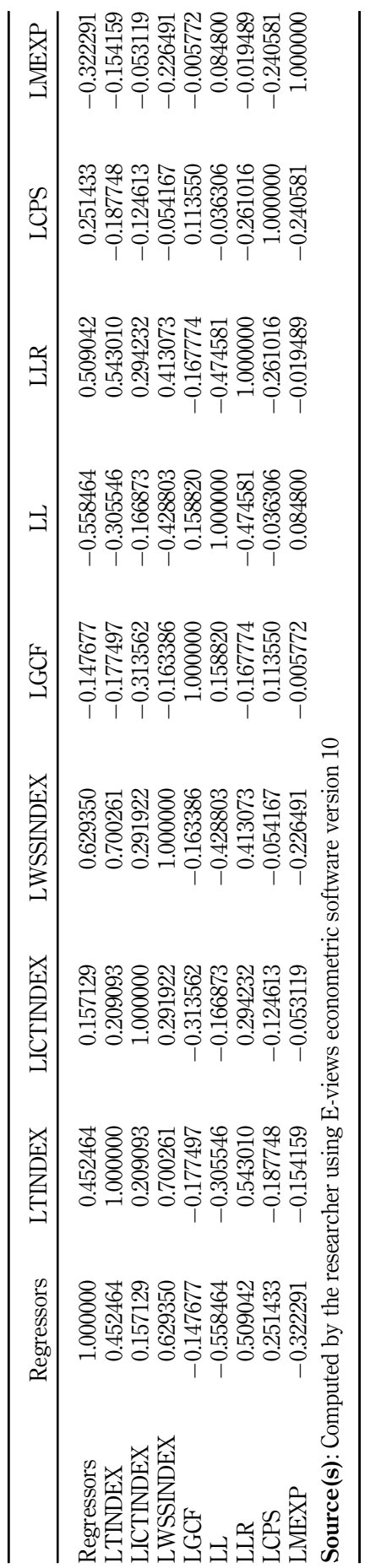

Infrastructure and industrial productivity sector

103

Table V. Result of correlation analysis and multicollinearity test 


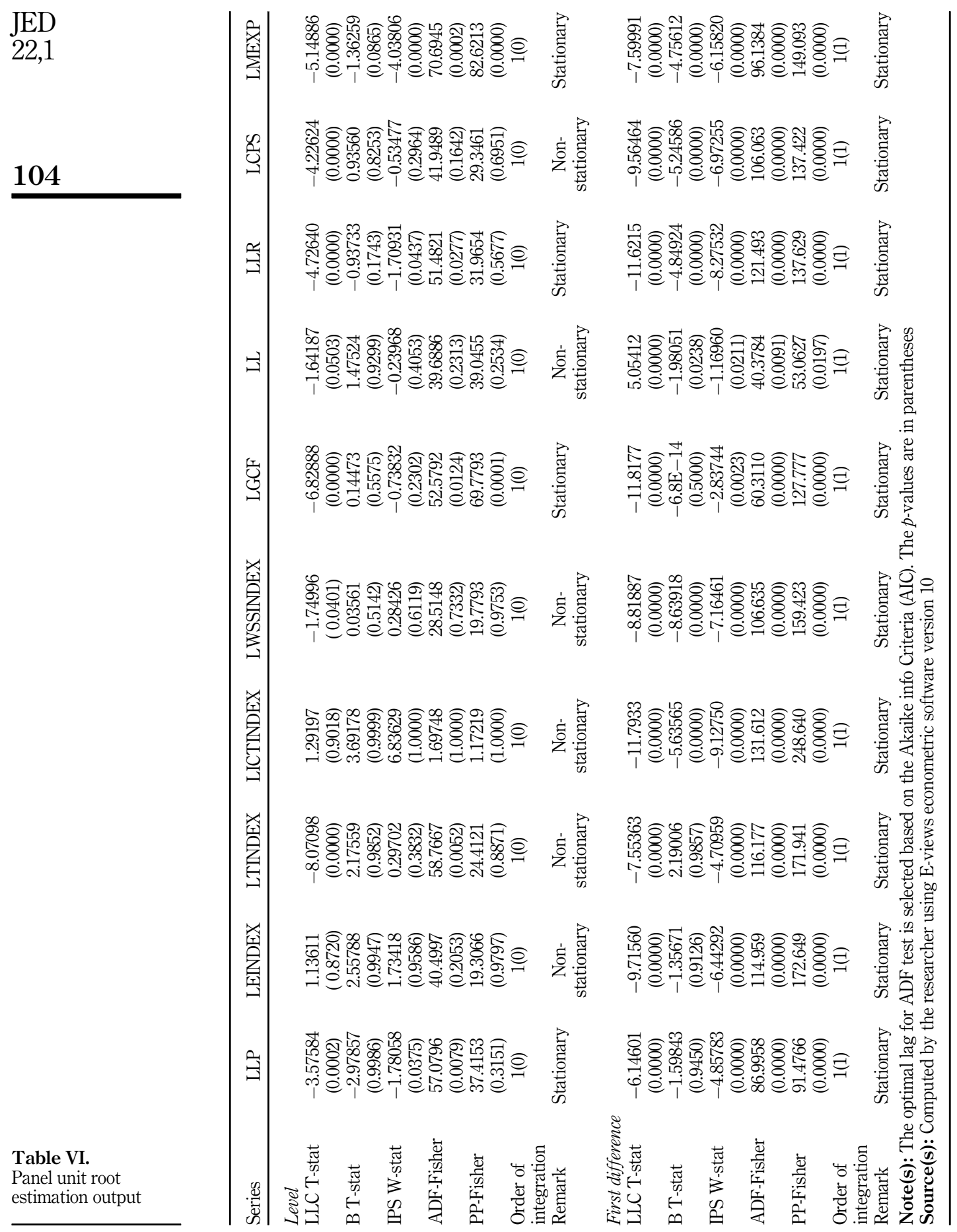


6,500 kWh in Europe. Also, the negative relationship between electricity infrastructure and industrial sector productivity authenticates the most recent observation of the African development Africa Development Bank (2018a) that electricity costs three times more in Africa than in comparable developing regions, and most manufacturers operating in West and East Africa have to rely on expensive backup generators as a primary energy source, which adversely affects their profit margins. This perhaps may have affected their productivity.

Also, the transport index was also insignificant, confirming the World Bank (2017a) observation that transport infrastructure is likewise lagging, with the region registering the lowest road and railroad densities among developing regions. Also, it supports the study conducted by Limao and Venables (2001), who found out that a deterioration of infrastructure raises transport costs and reduces trade volume.

However, it was only ICT index that exhibited a significant positive relationship with industrial sector productivity and was equally in line with the World Bank (2017a) observation that Sub-Saharan Africa has seen dramatic improvement in the quantity and quality of telecommunication infrastructure, and the gains are broad-based. That of water supply and sanitation index was negative and insignificant. The negative relationship signifies that even with an increase in the region's water supply and sanitation index, there was a reduction in industrial sector productivity by 18.4 per cent. This confirms the report of the African Union (2014) that the region has ample water resources, but they are underdeveloped, unsustainably managed and underutilized, with only 5 per cent of agriculture using irrigation. Agriculture constitutes the main source of supply of raw materials to the industrial sector, and ineffective utilization of water supply for irrigation purposes will lead to shortage in the supply of raw materials to the industrial sectors.

Correlated random effects - Hausman test

Equation: untitled

Test cross-section random effects

Test summary

Cross-section random

Chi-sq. Statistic

15.202657

Chi-sq. d.f.

9

Prob.

0.0855

Source(s): Computed by the researcher using E-views econometric software version 10
Infrastructure and industrial sector productivity

105

\begin{tabular}{lrrrr}
\hline & \multicolumn{2}{c}{ Random effect model } & & \\
Regressors & Coefficient & Std. Error & $t$-Statistic & Prob. \\
\hline C & 9.234943 & 0.220932 & 41.79992 & 0.0000 \\
LEINDEX & -0.039021 & 0.030772 & -1.268046 & 0.2068 \\
LTINDEX & 0.001309 & 0.011085 & 0.118053 & 0.9062 \\
LICTINDEX & 0.045968 & 0.014267 & 3.222010 & 0.0016 \\
LWSSINDEX & -0.183551 & 0.122742 & -1.495431 & 0.1370 \\
LGCF & 0.019318 & 0.006024 & 3.206766 & 0.0016 \\
LL & 0.102154 & 0.698657 & 0.146215 & 0.8840 \\
LLR & -0.126847 & 0.031828 & -3.985368 & 0.0001 \\
LCPS & 0.060939 & 0.027965 & 2.179124 & 0.0309 \\
LMEXP & -0.056441 & 0.030787 & -1.833275 & 0.0688 \\
$R$-squared & & 0.296725 & & \\
Adjusted $R$-squared & & 0.253373 & & \\
$F$-statistic & & 6.844478 & & \\
Prob $F$-statistic) & & 0.000000 & & \\
Durbin-Watson stat & & 0.620997 & &
\end{tabular}

Source(s): Computed by the researcher using E-views econometric software version 10

Table VIII. Panel least square estimation outputdependent variable: LLP 
JED

22,1

106

Finally, the control variables' lending rate and military expenditure have negative effect on industrial sector productivity. This negative relationship between lending rate and industrial sector productivity shows that commercial banks' lending rate in Sub-Saharan Africa are high, and the increase discouraged people from borrowing for investment purposes and thus led to a reduction in industrial sector productivity by 12.7 per cent. An increase in military expenditure led to a reduction in industrial sector productivity by 5.6 per cent, showing that the impact of the expenditure is not felt on the economy as most countries within the region are still facing challenges in terms of security and hence reducing the level of investment in the country. Military expenditure does not influence industrial sector productivity significantly, while lending rate has significant influence on industrial sector productivity. That of capital and credit to private sector was positive and significant showing improvement or additional investment in capital goods hence making industries more productive and efficient and also leading to the effectiveness of banks in financing the industrial sectors of the economy, while labour has positive and insignificant effect on industrial sector productivity in Sub-Saharan Africa.

\section{Conclusion}

This study attempted to complement the dearth in knowledge by investigating the relationship between infrastructure development and industrial sector productivity in Sub-Saharan Africa. The study, pooling seventeen countries as group (namely Nigeria, South Africa, Kenya, Mauritius, Botswana, Mauritania, Burkina Faso, Democratic Republic of Congo, Gambia, Guinea Bissau, Liberia, Madagascar, Malawi, Mali, Togo, Tanzania and Uganda), spanned from period 2003 to 2018. This study uses panel least square estimation method and finds statistical significance relationship between telecommunication infrastructure and industrial sector productivity in Sub-Saharan Africa. While on the other hand, the study found a statistical insignificance relationship between electricity infrastructure, transport infrastructure and water supply and sanitation infrastructure and industrial sector productivity. Thus, the study concludes that the relatively low level of industrial sector productivity in Sub-Saharan Africa is largely due to their poor electricity and transport infrastructure and underutilization of water supply and sanitation infrastructure.

One way to solve this deficit in electricity and transport infrastructure is the government's partnering with other developed countries of the world such as Germany, Japan, Sweden, Netherlands, Austria, Singapore, United States of America, United Kingdom, Switzerland and United Arab Emirates, which are the top ten countries in infrastructure ranking as currently released by the World Bank, thus equally extending their quality infrastructure to their own country for enhanced industrialization.

\section{References}

Abbas, F. and Choudhury, N. (2013), "Electricity consumption-economic growth Nexus: an aggregated and disaggregated causality analysis in India and Pakistan”, Journal of Policy Modeling, Vol. 35 No. 4, pp. 538-553.

Africa Development Bank. (2018a), African Economic Outlook, African Development Bank Group, Ivory Coast, Abidjan.

African Development Bank (2018b), "The Africa infrastructure development index", Statistics Department, available at: http://afdb.org (accessed 16 August 2019).

African Union (2014), "Programme for infrastructure development in Africa (PIDA): addressing the infrastructure gap in Africa, to speed up regional integration”, Seventh Conference of African Ministers in Charge of Integration, 14-18 July, Swaziland. 
Ahmed, E.M. and Krishnasamy, G. (2012), "Telecommunications investment and economic growth in ASEAN 5: an assessment from UECM", New Zealand Economic Papers, Vol. 46 No. 3, pp. 315-332.

Ajakaiye, O. and Ncube, M. (2010), "Infrastructure and economic development in Africa", Journal of African Economies, Vol. 19 Supplement 1, pp. i3-i12, AERC.

Infrastructure and industrial sector productivity

Ansar, A., Flyvbjerg, B., Budzier, A. and Lunn, D. (2016), "Does infrastructure investment lead to economic growth or economic fragility? Evidence from China", Oxford Review of Economic Policy, Vol. 32 No. 3, pp. 360-390.

Ayogu, M. (2007), "Infrastructure and economic development in Africa: a review", Journal of African Economies, Vol. 16 Supplement 1, pp. 75-126, AERC.

Berechman, J., Ozmen, D. and Ozbay, K. (2006), "Empirical analysis of transportation investment and economic development at state, county and municipality levels", Transportation, Vol. 33, pp. 537-551.

Breitung, J. (2000), "The local power of some unit root tests for panel data. Advances in Econometrics", in Baltagi, B.H., (Ed.), Non-Stationary Panels, Panel Cointegration, and Dynamic Panels, JAY PressAmsterdam, Vol. 15, pp. 161-178.

Bullock, R. (2009), Off Track: Sub-saharan African Railways. Africa Infrastructure Country Diagnostic (AICD) Background, Paper No. 17, The World Bank, Washington, DC.

Calderón, C. and Servén, L. (2010), "Infrastructure and economic development in sub-saharan Africa", Journal of African Economies, Vol. 19 S1, pp. 13-87.

Calderón, C., Cantú, C. and Chuhan-Pole, P. (2018), Infrastructure development in Sub-Saharan Africa, World Bank Group, Policy Research Working Paper, p. 8425.

Cantos, P., Gumbau-Albert, M. and Maudos, J. (2005), "Transport infrastructures, spillover effects and regional growth: evidence of the Spanish case", Transportation Review, Vol. 25, pp. 25-50.

Chakraborty, C. and Nandi, B. (2011), "Mainline telecommunications infrastructure, levels of development and economic growth: evidence from a panel of developing countries", Telecommunications Policy, Vol. 35 No. 1, pp. 441-449.

Chandran, V.G.R., Sharma, S. and Madhavan, K. (2010), "Electricity consumption-growth nexus: the case of Malaysia", Energy Policy, Vol. 38 No. 1, pp. 606-612.

Choi, I. (2001), "Unit root tests for panel data", Journal of International Money and Finance, Vol. 20 No. 2, pp. 249-272.

Cieslik, A. and Kaniewsk, M. (2004), "Telecommunications infrastructure and regional economic development: the case of Poland", Regional Studies, Vol. 38 No. 6, pp. 713-725.

Datta, A. and Agarwal, S. (2004), "Telecommunications and economic growth: a panel data approach", Applied Economics, Vol. 36 No. 15, pp. 1649-1654.

Deng, T.T., Shao, S., Yang, L.L. and Zhang, X.L. (2014), "Has the transport-led economic growth effect reached a peak in China? A panel threshold regression approach", Transportation, Vol. 41, pp. 567-587.

Dutta, A. (2001), "Telecommunications and economic activity: an analysis of Granger causality", Journal of Management Information Systems, Vol. 17 No. 4, pp. 71-95.

Erenberg, S.J. (1993), "The real effects of public investment on private investment", Applied Economics, Vol. 23, pp. 831-837.

Fedderke, J. and Garlick, R. (2008), Infrastructure Development and Economic Growth in south Africa: A Review of the Accumulated Evidence, Economic Research Southern Africa, Policy Paper, 12, University of Cape Town, South Africa.

Fisher, R.A. (1932), Statistical Methods for Research Workers, 4th ed., Oliver and Boyd, Edinburgh.

Foser, V. and Briceño-Garmendia, C. (Eds) (2010), Africa's Infrastructure: A Time for Transformation, The World Bank, Washington, DC. 
JED

22,1

108

Fouquet, R. (2008), Heat, Power and Light: Revolutions in Energy Services, Edward Elgar, Cheltenham, UK.

Gafer, T.I. and Saad, B.A. (2009), "An empirical analysis of the effect of infrastructure on industrialization in Nigeria, 1980-2005", Journal of International Economic Review, Vol. 2 Nos 1/2, pp. 135-149.

Greenstein, S.M. and Spiller, P.T. (1996), "Modern telecommunications infrastructure and economic activity: an empirical investigation", Industrial and Corporate Change, Vol. 4 No. 4, pp. 647-665.

Gujarati, D.N., Porter, D.C. and Gunasekar, S. (2012), Basic Econometrics, 5th ed., Tata Mc Graw-Hill Pvt. Ltd, US.

Hardy, A.P. (1980), "The role of the telephone in economic development", Telecommunications Policy, Vol. 4 No. 4, pp. 278-286.

Hong, J.J., Chu, Z.F. and Wang, Q. (2011), "Transport infrastructure and regional economic growth: evidence from China”, Transportation, Vol. 38, pp. 737-752.

Hulten, C., Bennathan, E. and Srinivasan, S. (2006), "Infrastructure, externalities, and economic development: a study of Indian manufacturing industry", The World Bank Economic Review, Vol. 20, pp. 291-308.

Im, K.S., Pesaran, M.H. and Shin, Y. (2003), "Testing for unit roots in heterogeneous panels", Journal of Econometrics, Vol. 115 No. 1, pp. 53-74.

International Energy Agency (2017), "World energy access outlook report", available at: http://www. iea.org (accessed4 August 2019).

Kander, A., Malanima, P. and Warde, P. (2014), Power to the People: Energy in Europe over the Last Five Centuries, Princeton University Press, New Jersey.

Kodongo, O. and Ojah, K. (2016), "Does infrastructure really explain economic growth in Sub-Saharan Africa?”, Review of Development Finance, Vol. 6, pp. 105-125.

Lean, H.H. and Smyth, R. (2014), Electricity Consumption, Output, and Trade in Bhutan, Asian Development Bank (ADB) South Asia working paper series, No. 34, Manila.

Levendis, J. and Lee, S.H. (2013), "On the endogeneity of telecommunications and economic growth: evidence from Asia”, Information Technology for Development, Vol. 19 No. 1, pp. 62-85.

Levin, A., Lin, C.F. and Chu, C.S. (2002), "Unit root tests in panel data: asymptotic and finite sample properties", Journal of Econometrics, Vol. 108 No. 1, pp. 1-24.

Limao, N. and Venables, A.J. (2001), "Infrastructure, geographical disadvantage, transport costs and trade", The World Bank Economic Review, Vol. 15 No. 3, pp. 451-479.

Maddala, G.S. and Wu, S. (1999), "A comparative study of unit root tests with panel data and a new simple test", Oxford Bulletin of Economics and Statistics, Vol. 61 S1, pp. 631-652.

Mehmood, B. and Siddiqui, W. (2013), "What causes what? Panel cointegration approach on investment in telecommunications and economic growth: case of Asian countries", Romanian Economic Journal, Vol. 16 No. 47, pp. 3-16.

Murphy, K., Shleifer, A. and Vishny, R.W. (1989), "Industrialization and big push”, Journal of Political Economy, Vol. 97 No. 5, pp. 1003-1026.

Norton, S.W. (1992), "Transaction costs, telecommunications, and the microeconomics of macroeconomic growth", Economic Development and Cultural Change, Vol. 41 No. 1, pp. 175-196, Oct.

Olowofeso, E.O., Adeleke, A.O. and Udoji, A.O. (2015), "Impact of private sector credit on economic growth in Nigeria", Central Bank of Nigeria Journal of Applied Statistics, Vol. 6 No. 2, pp. 81-100.

Olufemi, E.A., Olatunbosun, A.J., Olasode, O.S. and Adeniran, I.G. (2013), "Infrastructural development and its effect on economic growth: the Nigerian perspective", European Scientific Journal, Vol. 9 No. 31, pp. 431-452.

Phiri, A. and Bothwell, N. (2015), Re-visting the Electricity-Growth Nexus in South Africa, Studies in Business and Economics, Vol. 11 No. 1, pp. 97-111. 
Rodrigue, J.P. and Nottenboom, T. (2013), “Transportation and economic development”, The Journal of Geography of Transportation, pp. 1-29.

Roller, L. and Waverman, L. (2001), "Telecommunications infrastructure and economic development: a simultaneous approach", American Economic Review, Vol. 91 No. 4, pp. 909-923.

Shiu, A. and Lam, P.L. (2008a), "Causal relationship between telecommunications and economic growth in China and its regions", Regional Studies, Vol. 42 No. 5, pp. 705-718.

Smith, T. (1994), "The impact of highway infrastructure on economic performance", Spring, Vol. 57 No. 4.

Infrastructure and industrial sector productivity

Tatyana, P. (2015), "Assessing the impact of infrastructure on economic growth and global competitiveness", Procedia Economics and Finance, Vol. 23, pp. 168-175.

Umofia, N., Orji, K.E. and Worika, I.L. (2018), "Infrastructural development and the Nigerian industrial sector performance", International Journal of Scientific Engineering and Research, Vol. 9 No. 6, pp. 331-335.

United Nations Economic Commission for Africa (UNECA) (2006), Assessing Regional Integration in Africa, ECA Policy Research Paper, UNECA, Addis Ababa.

Wing, I.S., Anderson, W.P. and Lakshamanan, T.R. (2008), The Broader Benefits of Transport Infrastructure, Centre for Transport Studies, Boston.

World Bank (2017a), “Africa's pulse”, World Bank Group, Washington, DC, available at: http://docu ments.worldbank.org/curated/en/348741492463112162/Africas-pulse (accessed 21 July 2019).

World Bank (2017b), World Development Indicators, World Bank, Washington, DC.

World Health Organization (WHO) and UNICEF (2014), Progress on Drinking Water and Sanitation: 2014 Update, WHO and UNICEF, Switzerland.

Yoo, S.H. and Kwak, S.J. (2004), "Information technology and economic development in Korea: a causality study", International Journal of Technology Management, Vol. 27 No. 1, pp. 57-67.

\section{Corresponding author}

Chukwuebuka Bernard Azolibe can be contacted at: cb.azolibe@unizik.edu.ng

For instructions on how to order reprints of this article, please visit our website:

www.emeraldgrouppublishing.com/licensing/reprints.htm

Or contact us for further details: permissions@emeraldinsight.com 